Journal of Mechanical, Civil and Industrial Engineering

ISSN: $2710-1436$

DOI: $10.32996 /$ jmcie

Journal Homepage: www.al-kindipublisher.com/index.php/jmcie

\title{
Designing of The Propellant Cutting Machine Used Anthropometric Method
}

\author{
Wely Pasadena ${ }^{1} \square$ Timbul Siahaan ${ }^{2}$ and Pujo Widodo ${ }^{3}$ \\ ${ }^{12}$ Study program of Defense Industry, The Republic of Indonesia Defense University, Jakarta, Indonesia \\ ${ }^{3}$ Study Program of Asymmetrical Warfare, The Republic of Indonesia Defense University, Jakarta, Indonesia \\ $\square$ Corresponding Author: Wely Pasadena, E-mail: welypasadena24@gmail.com
}

ARTICLE INFORMATION ABSTRACT

Received: 09 October 2021

Accepted: 16 November 2021

Published: 02 December 2021

DOI: 10.32996/jmcie.2021.2.2.5

\section{KEYWORDS}

Design, Propellant Cutting

Machine, Anthropometry
Designing a machine relates to the human factor. The size of the human body and machine can cause problems due to mismatch. So that, size of the human body into consideration in the design of the machine is very important. The shape and size of the machine that is not suitable will cause difficulties for the operator in carrying out their activities. The purpose of this research was to design propellant cutting machine sizes based on anthropometry. The research method is based on the anthropometry of Indonesia. Anthropometry tools obtained the size of the minimum height of the machine, the maximum width of the machine, and also the maximum height of the table. The Result dimension of the height of the machine was $1792 \mathrm{~mm}$ and the width of the machine was $300 \mathrm{~mm}$ while the height of the machine table was $932 \mathrm{~mm}$. The position of the operator control was $95 \mathrm{~mm}$ from the floor.

\section{Introduction}

Ballistic rockets or missiles use solid propellants as fuel. (Waruwu,2013) A propellant is a chemical compound that has a high energy generation capability, which can be used as a rocket booster energy generator, as well as explosives.

The technology of solid propellants is needed in defense operations. To improve the ability of defense technology, for this reason, research and development of rockets are carried out by domestic institutions and industries. Including the manufacture of supporting equipment in the production of propellants.

Indonesia is now capable of producing propellant by the research institution. Collaborated research institutions and the defense industry improve the ability. Currently, the propellant cutting machine is not owned by the defense industry. For this reason, a propellant cutting machine is needed to support domestic production.

Propellant production requires several stages in the manufacturing process such as mixing, molding, and cutting. In the manufacturing process, a cutting process is required to match the design requirements. The length of propellant required depends on the design of the rocket.

Cutting propellant is needed high accuracy. The operator's accuracy in operating the cutting machine is influenced by the design of the cutting machine. The position of the visibility of the operator is also the reach of the operator's hand.

Designing a product is not only producing new products but it should support human work and be safe to use. The design of cutting machines by considering the anthropometry of workers is very important especially accuracy and productivity. The data is used anthropometric of Indonesian. To obtain accuracy in operation, it is necessary to design a cutting machine that is suitable for the worker.

Copyright: (C) 2021 the Author(s). This article is an open access article distributed under the terms and conditions of the Creative Commons Attribution (CC-BY) 4.0 license (https://creativecommons.org/licenses/by/4.0/). Published by Al-Kindi Centre for Research and Development, London, United Kingdom. 


\section{Literature Review}

In general, humans are different in terms of the shape and dimensions of their bodies to be applied in various product designs or work facilities (Nofirza, 2012). According to Wignjosoebroto (2008), anthropometry is a science that deals with measurements of the human body such as body weight, standing position, stretching of arms, and so on. According to Nurmianto (1991), anthropometry is a collection of numerical data related to the physical characteristics of the human body size, shape, and strength as well as the application of these data for handling design problems.

Purnomo (2013) stated that the design of the machine and human systems as well as the design of workstations cannot be separated from the interdependence of all design parties. It has several goals such as comfort, accuracy, and increasing work productivity. Wedantara (2018) pointed out that when doing work with a forced labor attitude because the tools used are not in accordance with the anthropometry of the body, the workload will feel heavier causing the pulse rate to increase. From a system perspective, a better system can only work if the system consists of, namely: First, System elements that have been designed according to what is needed. Second, System elements that interact with each other in an integrated manner in the business towards a common goal (Sunarso, 2010).

(Taifa, 2017) Anthropometry has three major principles. These principles are mainly being followed in designing various products depending on the type of product. The first principle is "design for extreme individual" which can be either designed for the maximum population as commonly the 95th percentile male or designed for the minimum population value as commonly referred to as 5th percentile female. The second principle is "designing for an Adjustable Range" which puts consideration of both 5 th female and 95th male to accommodate $90 \%$ of the population. The adjustability principle has been much suggested by many researchers as the main ergonomics principle to be followed in designing furniture. The principle is "designing for the average" which is mostly being used whenever the use of adjustability is impractical.

\section{Methodology}

This research used the anthropometry method. The anthropometry data were used male gender. Anthropometric data was used for various purposes such as in the design of equipment shown in figure 1.

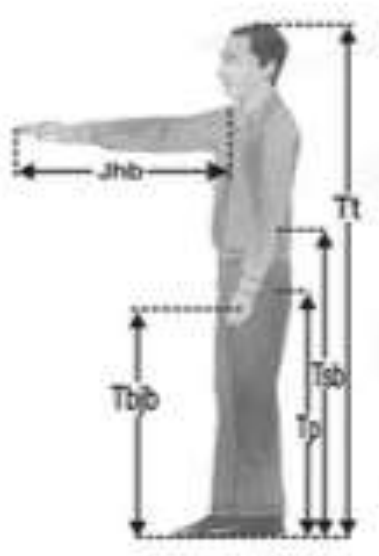

Figure 1 Body dimensions measured for standing position

Standing Elbow Height (Tsb) according to (Purnomo. 2013), this dimension is measured from the floor to the bottom of the elbow vertically in a standing position. This position is used in designing the maximum height of the workbench surface for a standing position. Standing horizontal reach (jhb) according to (Purnomo. 2013) where the dimensions are measured from the acromial bone to the fingertips horizontally in a sitting position or a standing position. This allows the operator to operate the equipment without having to bend or tilt the body.

(Zander.1972) For the designer's purpose, it is not necessary to work with the data on all 100 percentiles. Normally, the collection of human engineering data skip the first and the last five percentiles.

Percentile 5th $=X-1,645 . S D$

Percentile 95th $=X+1,645 . S D$ 


\section{Results and Discussion}

Conceptual design in the design of this cutting machine used a hydraulic system where the direction of the cutting motion is vertical-friction during cutting less than saw method. The machine is operated by one worker. The Propellant is put on the machine, attach a clamp and run the cutter.

The capacity of the machine is designed for propellant caliber 122 until $200 \mathrm{~mm}$. The power of the machine used a hydraulic system.

The data are used anthropometry Indonesian. We assumed workers are male gender.

Table 1: Indonesian Anthropometry Data (all dimension in $\mathrm{mm}$ )

\begin{tabular}{llllll}
\hline Dimension & Description & $\mathbf{5}^{\text {th }}$ & $\mathbf{5 0}^{\text {th }}$ & $\mathbf{9 5}^{\text {th }}$ & SD \\
\hline $\mathrm{Tt}$ & Body Height & 1532 & 1632 & 1732 & 61 \\
$\mathrm{Tsb}$ & Elbow Height & 932 & 1003 & 1074 & 43 \\
$\mathrm{Jhb}$ & $\begin{array}{l}\text { Long arm span } \\
\text { forward }\end{array}$ & 649 & 708 & 767 & 37 \\
& & & & &
\end{tabular}

Source: (Nurmianto, 1991)

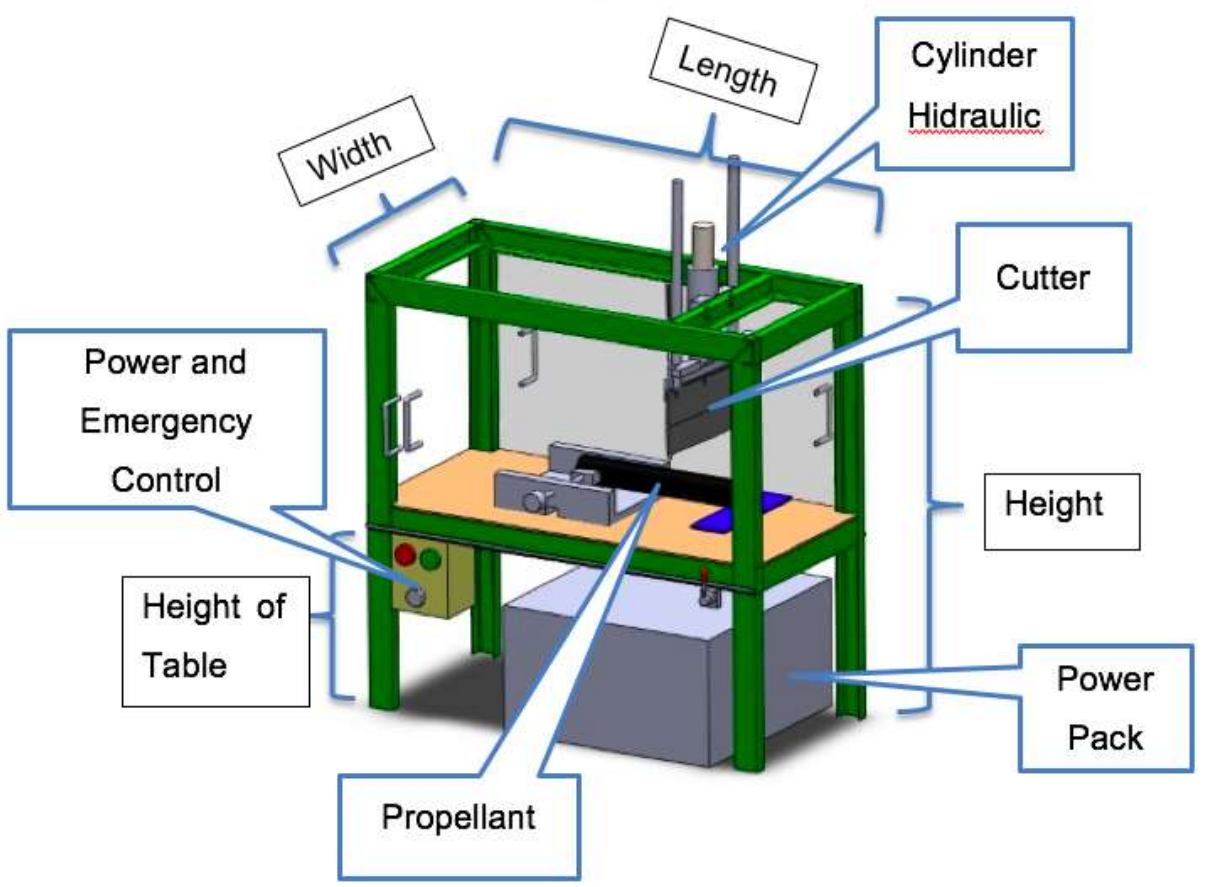

Figure 1 Propellant cutting machine

Figure 1 shows the design of the propellant cutting machine. The machine will be operated by one worker. All of the control panels were attached on one side-the electrical button on the left hand and the control hydraulic on the hand of the worker.

\subsection{Height of the Machine}

The percentile used is 95th, which is to prevent the operator from being hit by a head injury with the upper frame of the machine. Head protection height $=50 \mathrm{~mm}$

Safety shoe base height $=15 \mathrm{~mm}$

Height of machine $=1732+50+15=1792 \mathrm{~mm}$

\subsection{Width of the Machine}


Determined using 50th percentile data so that operators who are tall or short can easily reach them $614 \mathrm{~mm}$

Dimensions of material cut $=102-200 \mathrm{~mm}$

Width specified $300 \mathrm{~mm}<614 \mathrm{~mm}$

\subsection{Height of the table}

The 5 th percentile is used so that operators who have a low body have no difficulty operating the machine.

Table height $932 \mathrm{~mm}$

\subsection{Design Size Specification}

The propellant cutting machine has specifications and sizes that can be seen in the following table 2:

Table 2: Specification of The Cutting Machine Propellant

\begin{tabular}{lllll}
\hline Items & Specification & Score & Percentile & Dimension \\
\hline Height & UNP 80 & & $95^{\text {th }}$ & $1792 \mathrm{~mm}$ \\
Width & UNP 80 & $250 \times 150 \mathrm{~mm}$ & $50^{\text {th }}$ & $300 \mathrm{~mm}$ \\
Table Height & & & $250 \times 150 \mathrm{~mm}$ \\
Cutting motion & Vertical range & $100 \mathrm{~mm}$ & - & $100 \mathrm{~mm}$ \\
Drive type & Hydraulic & Diameter $80 \mathrm{~mm}$ & - & - \\
Power pack & Hydraulic oil & 40 liters & - &
\end{tabular}

\subsubsection{Design Working Principle}

The working principle of this propellant cutting tool is to be used on solid propellants with a diameter of 102-200 mm. The propellant is placed in the center of the machine and positioned right on the blade, the lever is moved and the blade will cut in a vertical motion

\section{Conclusion}

The data of the anthropometry can be used to design a machine to define design requirements. This method made designer easier for dimension decisions. Body height, hand reach, and elbow height are the references in the machine design The result of the design minimum of the machine height is $1792 \mathrm{~mm}$. Its result has safety from a collision head of the worker and the body of the machine. The table height is $99 \mathrm{~mm}$ following the worker's anthropometry. The width of the table does not exceed the smallest percentile anthropometric data so that operators of any size can operate properly. In designing a machine used by humans, the operator must consider the size of the operator. The design in this study can still be developed further, such as an analysis of material handling propellants both before and after being cut.

Acknowledgments: We are thankful to "Rocket Technology Center" for their support and necessary facilities to carry out this study

Funding: This research received no external funding

Conflicts of Interest: The authors declare no conflict of interest.

\section{References}

[1] Waruwu, M M. (2013). Analisis Keselamatan pada Instalasi Sistem Pembuatan dan Pengujian Solid Propelant Double Base dari Minyak JarakJurusan Teknik Fisika UGM. Jurnal Teknik Fisika, Vol.2 No.1

[2] Wignjosoebroto, S. (2008). Ergonomi Studi Gerak dan Waktu. Surabaya: Guna Widya.

[3] Nurmianto, E. (1991) Ergonomi Konsep Dasar Dan Aplikasinya. Surabaya: Prima Printing

[4] Purnomo, H. (2013). Antropometri dan Aplikasinya. Yogyakarta: Graha Ilmu

[5] Wedantara, P. M. S. (2018). Modification of Pandan Cutting Machine Based on Anthropometry to Increasing Work Productivity. Jurnal Beta, Volume 6, No. 1

[6] Sunarso. (2010). Perancangan Troli sebagai alat bantu angkut galon air mineral dengan pendekatan anthropometri. Surabaya : Guna Widya.

[7] Taifa, I. W and Darshak A. D. (2017). Anthropometric measurements for the ergonomic design of student furniture in India. Engineering science and Technology, an Internasional Journal 20 (2017) 232-239

[8] Nofirza and Dedy S. (2012). Perancangan Alat Pemotong Nenas Yang Ergonomis untuk Meningkatkan Produktivitas. Jurnal Ilmiah Teknik Industri, 11(1)

[9] Antropometriindonesia.org. (2021). Antropometri Indonesia https://antropometriindonesia.org/index.php/detail/artikel/4/10/data_antropometri. Download tanggal 30 Oktober 2021

[10] Nurmianto, E. (1991). Ergonomi Konsep Dasar dan Aplikasinya. Prima Printing Surabaya 